\title{
Peranan Guru Sejarah dalam Menanamkan Rasa Nasionalisme Siswa Kelas X di SMA Negeri 14 Samarinda
}

\author{
Ayu Desi Indah Utami', Asnar ${ }^{2}$, Jawatir Pardosi ${ }^{3}$ \\ ${ }_{1}^{1}$ Mahasiswa Program Konsentrasi Pendidikan Sejarah Universitas Mulawarman \\ 2Dosen Program Konsentrasi Pendidikan Sejarah Universitas Mulawarman \\ 3Dosen Program Konsentrasi Pendidikan Sejarah Universitas Mulawarman \\ 2asnar@gmail.com,3pardosi.jawatir@gmail.com
}

\begin{abstract}
This research attempts to obtain information about the participation of teachers history in infuse of nationalism on student $X$ in senior high school 14 Samarinda. The results show that participations of teachers history in imparting flavor nationalism to their students class $x$ in senior high school 14 Samarinda is participation of teachers history in imparting flavor nationalism students are teachers as examples, teachers as inspiratory, teachers as a motivator, and teachers as an evaluator. History teacher found obstacles to imparting flavor nationalism to their students are background students is different, development of technology had an impact on thinking pattern students, the influence of the mass media, and facilities schools that had not yet fully sufficient in supporting teaching history.
\end{abstract}

Keywords: teacher of history, nationalism, Samarinda

\begin{abstract}
ABSTRAK
Tulisan ini mencoba untuk memperoleh informasi tentang partisipasi guru sejarah dalam menanamkan nasionalisme pada Siswa Kelas X di SMA 14 Samarinda. Hasilnya menunjukkan bahwa partisipasi guru sejarah dalam menanamkan rasa nasionalisme untuk kelas siswa mereka x di SMA 14 Samarinda adalah guru sebagai contoh, guru sebagai inspirator, guru sebagai motivator, dan guru sebagai evaluator. Hambatan yang dihadapi oleh guru sejarah dalam menanamkan rasa nasionalisme siswa adalah latar belakang siswa yang berbeda, perkembangan teknologi yang mempengaruhi pola pikir siswa, pengaruh media massa, fasilitas sekolah yang belum sepenuhnya cukup dalam mendukung mengajar sejarah.
\end{abstract}

Kata Kunci: guru sejarah, nasionalisme, Samarinda

\section{PENDAHULUAN}

Permasalahan sikap nasionalisme sudah menjadi tugas bersama, yakni dari keluarga, masyarakat, pemerintah. Baik orang tua, guru, maupun masyarakat diharapkan mampu memberikan contoh yang nyata hingga akhirnya tertanam dalam diri generasi muda sikap kebangsaan yang sebenarnya. Nasionalisme hari ini tentunya berbeda dengan nasionalisme pada masa penjajahan seperti yang dikemukakan oleh Utomo (1995) bahwa nasionalisme Indonesia adalah nasionalisme yang integralistik, dalam artian tidak membeda-bedakan masyarakat atas golongan, tetapi mengatasi segala keanekaragaman. Singkatnya nasionalisme Indonesia adalah mempersatukan dalam perbedaan 
(Bhineka Tunggal Ika). Banyak cara yang dapat dilakukan untuk menunjukkan rasa cinta terhadap tanah air, diantaranya belajar dengan baik demi mencapai citacita untuk mengisi kemerdekaan atau menunjukan sikap peduli pada negara dengan tidak acuh pada sekitar, menjaga dan memelihara alam semesta, serta menjaga kekayaan bangsa yang telah sekian lama diperjuangkan dan dibangun oleh para pejuang.

Nasionalisme yang harus dimiliki oleh seluruh warga negara dapat ditanamkan pada anak-anak, baik di rumah maupun di sekolah. Guru, orang tua, dan masyarakat setidak-tidaknya dapat menanamkan motivasi kepada siswa bagaimana agar mereka memiliki semangat belajar yang tinggi, hingga akhirnya dapat menggunakan ilmu mereka kelak untuk mencerdaskan generasi selanjutnya dengan mananamkan nilai-nilai kejujuran, toleransi, disiplin, dan mementingkan kepentingan bersama daripada kepentingan pribadi, serta menghargai orang lain.

Lembaga pendidikan dalam hal ini sekolah juga mempunyai kewajiban untuk menanam rasa nasionalisme siswa. Pendidikan diharapkan dapat memberikan kontribusi nyata dalam mengembangkan nilai-nilai yang dapat dijadikan pedoman bagi siswa dalam kehidupan nyata hingga terbentuklah karakter siswa yang mencintai bangsa dan negaranya.

Peranan guru menjadi sangat penting dalam pembentukan karakter siswa yang mempunyai rasa nasionalisme. Rasa nasionalisme yakni sesuatu yang harus dimiliki oleh setiap orang khususnya siswa, sehingga dalam proses pembangunan menjadi modal penting dalam kelangsungan kehidupan berbangsa dan bernegara. Seorang guru dalam proses belajar mengajar bukanlah sekedar menyampaikan materi, tetapi juga harus berupaya agar materi pelajaran yang disampaikan juga menjadi kegiatan yang menyenangkan, serta dapat menumbuhkan nilai karakter pada diri siswa. Semakin tinggi kemampuan guru dalam melaksanakan proses belajar mengajar, semakin tinggi pula keberhasilan guru dalam menanamkan nilai karakter siswa. Kesimpulan pernyataan ini bahwa pentingnya menanamkan rasa nasionalisme dalam pendidikan sangat dipengaruhi oleh kemampuan guru dalam mengelola proses pembelajaran di kelas.

Tulisan ini mencoba untuk menjelaskan tentang peranan guru sejarah dalam menanamkan rasa nasionalisme pada siswa Kelas X di SMA Negeri 14 Samarinda. Tulisan ini fokus pada pembahasan tentang peranan guru sejarah dalam menanamkan rasa nasionalisme pada siswa, hambatan- 
hambatan yang dihadapi dan upaya yang ditempuh dalam menanamkan rasa nasionalisme pada siswa.

\section{METODE}

Tulisan ini merupakan tulisan deskriptif kualitatif yang membahas tentang peranan guru sejarah dalam menanamkan nasionalisme pada siswa. Fokus tulisan ini dapat dijabarkan sebagai berikut:

1. Peranan seorang guru Sejarah dalam menanamkan sikap rasa nasionalisme pada siswa

a. Penanaman rasa cinta tanah air

b. Penanaman rasa dan upaya dalam menghargai jasa para pahlawan

c. Penanaman rasa rela berkorban untuk kepentingan bangsa dan negara

d. Penanaman rasa untuk mengutamakan persatuan dan kesatuan

e. Penanaman rasa dan upaya agar memiliki jiwa pembaharu dan tidak mengenal menyerah

f. Penanaman sikap tenggang rasa sesama manusia

2. Hambatan-hambatan yang muncul dalam menanamkan rasa nasionalisme pada siswa

a. Hambatan dalam fasilitas sekolah

b. Hambatan pada siswa

c. Hambatan pada perangkat pembelajaran sejarah
3. Upaya yang dilakukan guru sejarah dalam menanamkan rasa nasionalisme

a. Rasa nasionalisme yang ditanamkan melalui penyampaian materi sejarah

b. RPP dan Silabus sejarah kelas X untuk pedoman pembelajaran

c. Metode yang digunakan guru sejarah dalam penanaman rasa nasionalisme dalam pembelajaran sejarah

d. Media yang digunakan guru sejarah dalam penanaman rasa nasionalisme dalam pembelajaran sejarah

\section{HASIL DAN PEMBAHASAN}

\section{Peranan Guru Sejarah dalam Menanamkan Rasa Nasionalisme}

Berdasarkan kajian Pullias dalam Mulyasa (2005: 37) menegaskan bahwa sedikitnya ada 19 peran guru yakni guru sebagai pendidik, guru sebagai pengajar,guru sebagai pembimbing, guru sebagi pelatih, guru sebagai penasehat, guru sebagai pembaharu, guru sebagai model dan teladan, guru sebagai pribadi, guru sebagai peneliti, guru sebagai pendorong kreativitas, guru sebagai pembangkit pandangan, guru sebagai pekerja rutin, guru sebagai pemindah kemah, guru sebagai pembawacerita, guru sebagai aktor, guru sebagai emansipator, guru sebagai evaluator, 
guru sebagai pengawet, guru sebagai kulminator. Dalam kaitannya peranan guru sejarah dalam menanamkan rasa nasionalisme siswa ini adalah guru sebagai teladan, guru sebagai inspirator, guru sebagai motivator, guru sebagai dinamisator dan guru sebagai evaluator.

Guru sebagai motivator sangat erat kaitannya dengan pembentukan sikap nasionalisme. Motivasi dari guru dapat memberikan dorongan kepada siswa agar berani untuk mengeluarkan pendapatnya dan mempertanggungjawabkan jawaban yang telah disampaikan di dalam proses pembelajaran. Biasanya guru mengadakan pembelajaran dengan metode diskusi, dalam pelaksanaannya siswa diberikan kesempatan untuk berpendapat dan guru tetap memberikan pengarahan ketika jawaban yang dilontarkan belum sesuai dengan yang diharapkan. Oleh karena itu, dalam pelaksanaannya guru sebagai teladan dilakukan secara teoretis maupun praktek secara langsung.

Pemberian keteladanan yang baik dapat dicontohkan dari perjuangan para pahlawan. Diharapkan dengan memanfaatkan figur seorang pahlawan tersebut sanggup memberikan teladan yang bagus kepada siswa dalam menentukan sikap agar lebih mencintai tanah air. Perihal praktek keteladanan yang diharuskan untuk dilakukan oleh guru sejarah adalah mengenai kedisiplinan dalam pembelajaran baik disiplin mengenai waktu maupun disiplin dalam hal menyampaikan materi yang senantiasa harus sesuai dengan tujuan pembelajaran yang telah ditentukan. Guru sebagai inspirator mengarahkan siswa untuk mengoptimalkan segala potensi yang dimiliki. Guru melakukan usaha dalam mengubah mind set siswa agar lebih mencintai sejarah dengan tidak hanya menjelaskan tentang teori saja namun dapat dikembangkan menjadi penelitian secara ilmiah pada benda-benda sejarah.

Seorang guru tidak hanya membangkitkan semangat, tetapi juga menjadi lokomotif yang benar-benar mendorong gerbang ke arah tujuan dengan kecepatan, kecerdasan dan kearifan yang tinggi. Peran guru sebagai dinamisator telah dilakukan oleh guru sejarah di SMA Negeri 14 Samarinda yang mengajarkan bela negara guna menumbuhkan kecintaan pada tanah air, kesadaran berbangsa dan bernegara Indonesia, keyakinan akan kesaktian Pancasila sebagai ideologi negara, kerelaan berkorban untuk negara serta memberikan kemampuan awal bela negara.

Evaluasi atau penilaian dilakukan oleh guru guna mengetahui keberhasilan pencapaian tujuan, penguasaan siswa tehadap pelajaran, serta ketepatan atau keefektifan metode mengajar. Peranan 
guru sebagai evaluator adalah mengevaluasi pembelajaran yang dilakukukan untuk mewujudkan perubahan sikap siswa. Kaitannya guru sebagai evaluator dengan penanaman rasa nasionalisme adalah guru menjadi orang yang mengkaji apakah siswa yang diajarkan sudah mampu mengaktualisasi materi pelajaran nasionalisme dalam kehidupan sehari-hari. Hal ini dapat dilaksanakan ketika pelaksanan upaca bendera setiap hari senin. Guru selalu mengamati siswanya dalam pelaksanaan upacara, apabila terjadi keributan dalam kegiatan ini, maka guru tidak segan untuk memberikan peringatan kepada siswa yang melakukan kesalahan itu. Adapun cara lain yakni memberikan refleksi dan pengarahan di dalam kelas setiap selesai upacara bila ada contoh tindakan siswa yang tidak patut untuk dicontoh.

Hal tersebut dapat dikembangkan guru sebagai teknik dalam pembelajaran di dalam kelas, agar bisa menumbuhkan sikap ingin tahu siswa akan sejarah yang pernah ada di daerah sekitar tempat tinggal mereka. Guru sebagai motivator banyak memberikan pengaruh kepada siswa. Motivasi yang diberikan oleh guru adalah mengarahkan siswa untuk berani mengeluarkan pendapat, bertanggung jawab, dan juga lebih rajin membaca yang merupakan cerminan sikap nasionalisme.

\section{Hambatan dalam Penanaman Rasa Nasionalisme}

Pada tulisan ini, penulis ingin mengangkat peranan guru sejarah dan pendidikan karakter dalam pembentukan sikap nasionalisme ke guru dan siswa, juga meneliti tentang berbagai macam hambatan-hambatan guru sejarah dalam proses pembentukan sikap nasionalisme tersebut. Berdasarkan hasil observasi dan wawancara dengan guru sejarah, ada beberapa hambatan dalam proses pembentukan sikap nasionalisme siswa. Pertama, latar belakang dari tiap-tiap siswa sebagaimana yang diungkapkan oleh Dasa Tri Cahya Nugraha, S.Pd:

"Masing-masing siswa itukan memiliki latar belakang yang berbedabeda jadi untuk memahami mereka perlu pendekatan yang mampu membuat guru dan siswa saling mengerti karakter masing-masing". (hasil wawancara tanggal 4 Maret 2015).

Kedua, penanaman nasionalisme ini juga berkaitan dengan pendidikan yang ada di dalam keluarga, sifat anak yang manja karena memiliki latar belakang keluarga yang berkecukupan dan memiliki kemudahan untuk mendapatkan sesuatu yang diinginkan sehingga terdapat kesulitan untuk mengajarkan nasionalisme kepada mereka.

Rasa nasionalisme yang harus dimiliki oleh seluruh warga negara dalam praktiknya belum sepenuhnya terlaksana. Fenomena yang terjadi saat 
ini bahwa maraknya tindak korupsi dan generasi muda yang acuh dengan segala problematika yang ada menunjukkan sikap nasionalisme yang menurun. Untuk itu semua guru dalam khususnya guru sejarah dan pelaksanaan pendidikan karakter ini dapat menunjang pembentukan sikap nasionalisme tersebut. Namun dalam pelaksanaan pembentukan sikap nasionalisme ini, guru mengalami hambatan hambatan.

Hambatan dalam pembentukan sikap nasionalisme siswa di SMA Negeri 14 Samarinda. Pertama, adalah perbedaan latar belakang siswa, Kedua, penanaman rasa nasionalisme ini juga berkaitan dengan pendidikan yang ada di dalam keluarga. Ketiga, perkembangan alat komunikasi yang sangat pesat. Perkembangan teknologi yang canggih ini turut berdampak pada pola pikir siswa yang cenderung bersikap praktis tanpa adanya usaha, sehingga menghambat penanaman rasa nasionalisme. Keempat, pemberitaan di media massa tentang carut-marut keadaan politik yang merupakan contoh tidak baik bagi perkembangan siswa. Kelima, fasilitas sekolah yang belum sepenuhnya memadai. Penggunaan fasilitas sekolah guna menunjang pelaksanaan pembelajaran belum mendapat perhatian yang cukup dari pihak kepala sekolah.

\section{Upaya Guru Sejarah dalam Menanamkan Rasa Nasionalisme}

\section{Perencanaan Pembelajaran}

Perencanaan pembelajaran terdiri dari silabus dan RPP telah dicantumkan nilai-nilai karakter yang menjadi pedoman guru dalam menanamkan nilai-nilai nasionalisme pada diri siswa. Penyusunan silabus merupakan kerjasama antar guru sejarah di SMA Negeri 14 Samarinda, sehingga tidak ditemukan kendala berarti. Penambahan pemahaman yang diberikan oleh kepala sekolah dan wakil kepala sekolah di masukkan dalam silabus juga dapat berjalan dengan baik.

Berdasarkan hasil pengamatan guru sudah dapat memilih nilai-nilai nasionalisme yang sesuai dengan materi pelajaran sejarah dan sesuai kondisi siswa di kelas. Guru mampu mengembangkan nilai-nilai nasionalisme tersebut kedalam proses pembelajaran sejarah secara nyata.

\section{Pelaksanaan Pembelajaran}

Pelaksanaan pembelajaran sejarah oleh guru sejarah dalam rangka pembentukan sikap nasionalisme siswa berkaitan erat dengan penyampaian materi yang berkenaan dengan nasionalisme, strategi pembelajaran, media pembelajaran.

Materi sejarah yang terkait dengan nasionalisme mampu disampaikan guru secara baik. Guru mengaitkan tentang 
nasionalisme ini dengan berbagai peristiwa yang terjadi pada masa sekarang ini sehingga memudahkan siswa untuk memahaminya. Selain itu penjelasan materi sejarah dilakukan untuk membangkitkan minat siswa akan pelajaran sejarah yakni dengan selingan cerita maupun humor sehingga pembelajaran akan lebih menarik. Pada saat siswa sudah tertarik dengan pelajaran, maka akan lebih mudah untuk menjelaskan tentang makna yang terkandung dalam materi sejarah yang pada akhrinya dapat menjadi sebuah nilai atau pedoman siswa dalam bersikap.

Strategi pembelajaran adalah siasat yang sengaja direncanakan guru, berkenaan dengan segala persiapan pembelajaran agar pelaksanaan pembelajaran berjalan dengan lancar dan tujuan yang berupa hasil belajar bisa tercapai secara optimal, maka diperlukan satu metode pembelajaran yang tepat dalam mewujudkan tujuan pembelajaran tersebut. Salah satu metode yang digunakan dalam penanaman rasa nasionalisme adalah ceramah bervariasi, diskusi, pemutaran film, tanya jawab, penugasan. Penggunaan metode diskusi dan pemutaran film ini dirasa cukup efektif untuk menginternalisasikan nilai-nilai nasionalisme kepada siswa.

Film sejarah yang menceritakan tentang perjuangan para pahlawan mampu membangkitkan semangat nasionalisme siswa. Penggambaran tentang kerja keras dan bagaimana untuk menimbulkan rasa menghargai jasa para pahlawan sebagai wujud sikap nasionalisme.

Media pembelajaran menurut Sudjana dan Rivai (2009: 2) dapat meningkatkan proses belajar peserta didik dalam pengajaran yang gilirannya diharapkan dapat mempertinggi hasil belajar yang dicapainya. Alasan penggunaan media dalam pembelajaran antara lain: (1) pengajaran akan lebih menarik perhatian peserta didik sehingga dapat menumbuhkan motivasi belajar; (2) bahan pengajaran akan lebih jelas maknanya sehingga lebih dipahami oleh peserta didik; (3) metode mengajar akan lebih bervariasi; dan (4) peserta didik lebih banyak melakukan kegiatan belajar, sebab tidak hanya mendengarkan guru tetapi juga melakukan aktivitas lain seperti mengamati, melakukan, mendemonstrasikan, dan lain-lain.

Sadiman (2009:17) juga menjelaskan bahwa media mempunyai fungsi sebagai berikut: 1) memperjelas penyajian pesan agar tidak terlalu bersifat verbal, 2) mengatasi keterbatasan ruang, waktu dan daya indera, 3) penggunaan media pendidikan secara tepat dan bervariasi dapat mengatasi sikap pasif anak didik, dan 5) memberikan perangsangan dan 
pemgalaman yang sama, serta menimbulkan persepsi yang sama, meskipun latar belakang murid yang berbeda satu dengan yang lainnya.

Berdasarkan pemaparan di atas, media pembelajaran menjadi wahana untuk menanamkan rasa nasionalisme kepada siswa. Dalam hal ini, penggunaan media dimaksudkan aga terdapat persamaan persepsi antara guru dan siswa, sehingga tercipta kesamaan pola pikir yang akhirnya memberikan pemahaman yang sama tentang nasionalisme. Penggunaan media untuk menunjang pembentukan sikap nasionalisme diantaranya film sejarah, foto, dan artefak. Media digunakan untuk membuat siswa tertarik mempelajari sejarah secara lebih mendetail. Film sejarah dapat menggambarkan kerja keras para pahlawan bangsa sehingga dapat memberi semangat kepada generasi muda sekarang ini. Foto sejarah juga dapat dijadikan media yang membuat siswa semakin tertarik dengan sejarah dan bisa mengembangkannya menjadi wahana yang menyenangkan.

\section{Evaluasi Pembelajaran}

Evaluasi dilakukan tidak hanya mengukur pencapaian akademik siswa, melainkan juga mengukur bagaimana perkembangan tingkah laku siswa. Di sisi lain, evaluasi tidak terbatas kepada aspek akademik saja. Melainkan aspek praktiknya juga harus mendapatkan perhatian. Guru sejarah di SMA Negeri 14 Samarinda melakukan evaluasi pada aspek kognitif, afektif, dan psikomotorik.

Guru sejarah dalam evaluasi menggunakan teknik penilaian tes tertulis, tes lisan, dan tes penilaian sikap. Instrumen evaluasi yang disiapkan untuk hasil maksimal dalam menanamkan nilai-nilai nasionalisme adalah membuat kriteria ketuntasan minimal hasil pembelajaran, membuat soal-soal pilihan ganda, uraian, benar salah untuk aspek kognitif, tes tertulis keterampilan, tes pekerjaan rumah, tes lisan untuk aspek psikomotorik, lembar pengamatan membuat jurnal penilaian sikap siswa untuk aspek afektif.

Ulangan harian, remedial atau pengayaan akan dilaksanakan apabila terdapat siswa yang belum mencapai kriteria ketuntasan minimal. Penilaian sikap siswa dimasukkan ke dalam jurnal penelitian sikap yang dilakukan secara terbuka dengan siswa. Hal ini bertujuan agar siswa terus bersemangat dalam belajar dan memberikan efek jera kepada siswa. Hasil belajar dicatat dalam daftar nilai, penilaian sikap dicatat ke dalam jurnal.

\section{Ekstrakurikuler}

Kegiatan ekstrakurikuler merupakan kegiatan pendidikan di luar mata pelajaran dan pelayanan konseling untuk membantu pengembangan 
peserta didik sesuai kebutuhan, potensi, bakat, dan minat mereka melalui kegiatan yang secara khusus diselenggarakan oleh pendidik atau tenaga kependidikan yang berkemampuan dan berwenang di sekolah.

Ekstrakurikuler yang dapat menunjang pembentukan sikap nasionalisme siswa adalah pramuka. Kegiatan ekstrakurikuler ini dapat mengaplikasikan teori yang didapatkan dalam pembelajaran untuk dipraktekkan secara langsung dalam kehidupan nyata. Oleh karena itu, ekstrakurikuler Pramuka ini tentunya relevan untuk mengajarkan tentang cinta tanah air, selain itu juga mampu dalam menanamkan kedisiplinan, percaya diri, dan tanggung jawab.

\section{PENUTUP}

Guru sejarah memainkan peranan fundamental dalam menanamkan rasa nasionalisme pada siswa kelas X di SMA Negeri 14 Samarinda. Berdasarkan pembahasan dan temuan di lapangan, bahwa peran guru sejarah dalam menanamkan rasa nasionalisme siswa sangat menentukan. Hal ini cukup beralasan, mengingat guru sebagai teladan, guru sebagai inspirator, guru sebagai motivator, guru sebagai dinamisator, dan guru sebagai evaluator.

Adapun hambatan yang ditemui guru sejarah dalam menanamkan rasa nasionalisme pada siswa diantaranya latar belakang siswa yang berbeda-beda, perkembangan teknologi yang turut berpengaruh pada pola fikir siswa, pengaruh media masa, dan fasilitas sekolah yang belum sepenuhnya memadai dalam menunjang pembelajaran sejarah serta minimnya pertemuan jam pelajaran untuk mata pelajaran sejarah.

Upaya guru sejarah dalam menanamkan sikap nasionalisme siswa yang meliputi pembelajaran sejarah (perencanaan, pelaksanaan, evaluasi) dan kegiatan ekstrakurikuler.

Pada tahap perencanaan yang terdiri dari silabus dan RPP yang dirancang oleh guru sejarah. Tahap pelaksanaan meliputi penyampaian materi, strategi pembelajaran dan media pembelajaran yang disesuaikan dengan tujuan pembelajaran dan dapat membangkitkan minat belajar siswa dalam proses pembelajaran, kemudian tahap akhir adalah evaluasi yang dilakukan dengan pencatatan dijurnal sikap.

Kegiatan ekstrakurikuler yang menjadi wahana untuk menanamkan rasa nasionalisme dikalangan siswa adalah pramuka. Kegiatan ekstrakulikuler ini menjadi wadah untuk mempraktekkan secara langsung sikap nasionalisme dalam kehidupan nyata. Selain itu, penanaman rasa nasionalisme juga dilakukan melalui berbagai kegiatan rutin yang bertujuan memupuk rasa saling 
tolong-menolong, kerjasama dan gotong

royong untuk tercapainya suasana

harmonis di sekolah.

\section{REFERENSI}

Mudyahardjo, R. 2005. Pengantar Pendidikan. Jakarta: PT. Raja Grafindo Persada

Mulyasa, 2005. Peran Guru Sebagai Pendidik. Blog kita.blogspot.com

Sadiman, A S, Rahardjo, R., Haryono, A. dan Rahardjito. 2009. Media Pendidikan: Pengertian, Pengembangan dan Pemanfaatannya. Jakarta: Rajawali Pers.

Sudjana, N. dan Rivai, A. 2009. Media Pembelajaran. Bandung: Sinar Baru Algensindo

Suhartono, 2001. Sejarah Pergerakan Nasional: dari Budi Utomo sampai proklamasi 1900-1945. Jakarta: LP3ES

Usman, M. U. 2009. Menjadi Guru Profesional. Bandung: PT. Remaja Rosdakaya 